\title{
Genetic Relationships and Phylogeny of Papua New Guinean Hylid Frogs Elucidated by Allozyme Analysis
}

\author{
Masayuki SUMIDA, AlLen ALliSON, ANd Midori NISHIOKA
}

\begin{abstract}
To elucidate the evolutionary relationships of Papua New Guinean hylid frogs, we conducted an allozyme analysis using a total of 70 individuals from nine species of Litoria and two species of Nyctimystes. Fourteen enzymes extracted from skeletal muscles and livers were analyzed by starch-gel electrophoresis. These enzymes were encoded by genes at 20 presumptive loci. There were 3-11 phenotypes produced by 3-9 alleles at these loci. The mean proportion of heterozygous loci per individual, mean proportion of polymorphic loci per population, and mean number of alleles per locus in 11 species were $4.5 \%, 12.5 \%$, and 1.14 on average, respectively. Genetic distances were 0.036 between two populations of $L$. infrafrenata; $0.248-1.849(\overline{\mathbf{x}}=1.135)$ between nine species of the genus Litoria; and 1.703 between two species from the genus Nyctimystes. The intergeneric genetic distances were 1.551-2.877 $(\overline{\mathbf{x}}=1.944)$ between Litoria and Nyctimystes. The UPGMA dendrogram and NJ tree showed the primary dichotomy of the Papua New Guinean hylids Nyctimystes and Litoria. Our distance data confirmed the presence of several sibling species of Litoria, which are similar to each other in external morphology; i.e., L. arfakiana and L. wollastoni, and $L$. contrastens and $L$. bicolor group sp.
\end{abstract}

Key words: Allozyme analysis; Anura; Hylidae; Litoria; Nyctimystes; Phylogeny; Papua New Guinea

Six families of frogs are known to inhabit Papua New Guinea (Menzies, 1976). One of these (Bufonidae) contains only a single species, Bufo marinus, which was introduced from Hawaii in 1937, and another (Rhacophoridae) is known only from two specimens of Rhacophorus of possible artificial origin collected near Jayapura in 1926. Of the four remaining families, Myobatrachidae and Hylidae have affinities only with Australia, whereas Ranidae and Microhylidae are virtually absent from Australia and are obviously derived from the Oriental Region (Menzies, 1976).

According to Zweifel and Tyler (1982), our knowledge of the systematics of the New Guinean frog fauna is far from being complete, but is sufficient to establish the relative diversity within the anuran families and, hence, of the fauna as a whole. They listed 184 species of frogs for the New Guinean region. The Hylidae comprise more than $40 \%$ of the known species from New Guinea and are outnumbered only by the Microhylidae (Zweifel and Tyler, 1982). Two genera of Hylidae are recognized in New Guinea: Litor$i a$ with 52 species and Nyctimystes with 19 species (Zweifel, 1983). In an examination of the

Accepted 7 Nov. 1998 phylogenetic relationships and evolution of $\mathrm{Ny}$ ctimystes by skeletal characteristics, Tyler and Davies (1979) concluded that the genus probably derived from a montane Litoria stock resembling Litoria eucnemis.

An allozyme analysis of New Guinean frogs has resolved genetic relationships among several species within the genus Litoria (Dessauer et al., 1977). Dessauer et al. (1977) studied biochemical variation among 13 New Guinean species of Litoria, and recognized two major groups: one containing six species, and the other containing seven species. However, no Nyctimystes were included in the samples they analyzed, and the genetic relationships between genus Litoria and genus Nyctimystes have still not been reported by allozyme analysis.

In the present study, an allozyme analysis was carried out using 11 species of Litoria and $\mathrm{Ny}$ ctimystes to elucidate their genetic relationships at the genus, species, and population levels.

\section{Materials and Methods}

A total of 70 specimens from 11 species of Litoria and Nyctimystes were used (Table 1, Figs. 1 and 2). Of these, specimens of $L$. pratti group sp. and L. bicolor group sp. (Figs. 1E, F and $2 \mathrm{C}$ ) possibly represent undescribed species 


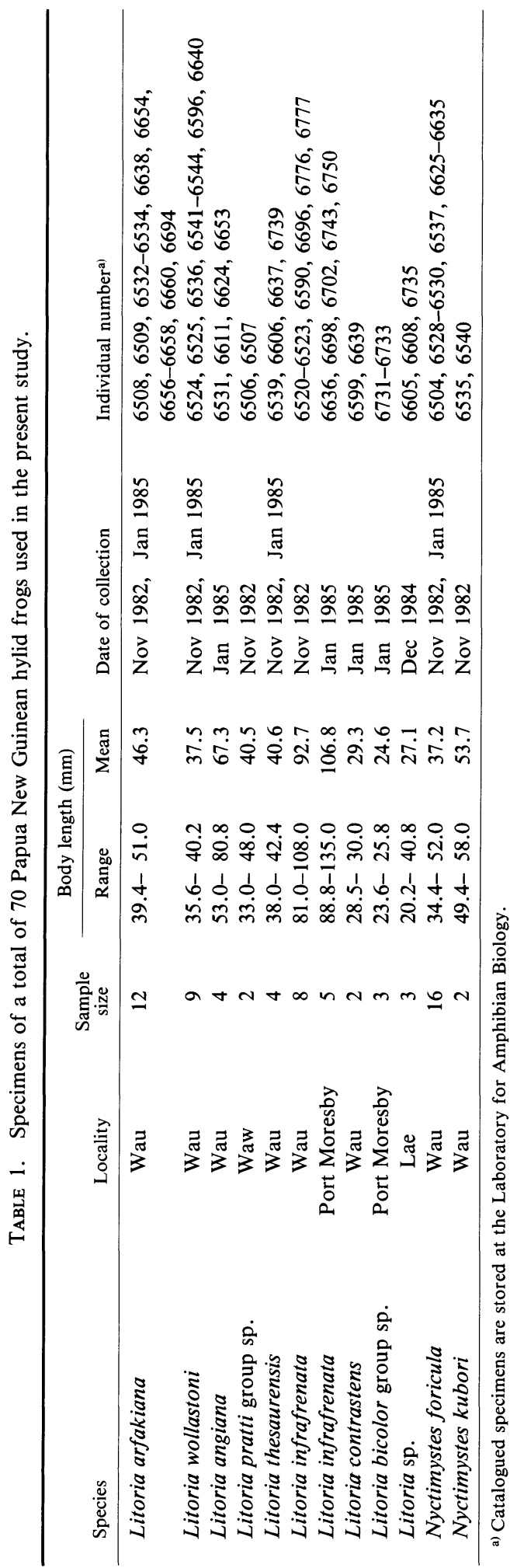

(Menzies, 1976). Three specimens of another seemingly undescribed species $(L$. sp.) were collected in the vicinity of Lae. These frogs were dark brown, blotched with a considerable amount of yellow, and had a light line connecting the upper eyelids (Fig. 2A). Litoria infrafrenata, which was shown to contain highly diverged populations (Dessauer et al., 1977), was collected from two different localities, Wau and Port Moresby, and these two local populations were treated as different OTUs. The other seven species were collected in the vicinity of Wau (Table 1).

Fourteen enzymes extracted from muscles and livers were analyzed by horizontal starch-gel electrophoresis following the method of Nishioka et al. $(1980,1992)$ (Table 2). The detection of each enzyme was carried out following the method outlined by Harris and Hopkinson (1976). The genetic distances were calculated following Nei (1972), and phenetic relationships were assumed by constructing dendrograms on the basis of the UPGMA method (Nei, 1975, 1987; Sneath and Sokal, 1973) and the NJ method (Saitou and Nei, 1987). In the NJ analysis, the root was assumed at the midpoint of the longest path.

\section{RESULTS}

The electrophoretic patterns of 14 enzymes analyzed were presumed to be encoded by genes at 20 loci. Electrophoretic bands corresponding to multiple alleles at each locus were named A, B, C, etc., in the order of greater mobility, and alleles were indicated by $a, b$, c, etc. The CK locus was least variable; three phenotypes were produced by three alleles. The IDH-1 locus was the most polymorphic; 10 phenotypes were produced by nine alleles. At the 20 loci examined, there were 6.5 phenotypes produced by 5.3 alleles on average (Table 3). Table 4 presents gene frequencies for each species at 20 loci. At seven loci (AAT-1, IDH-1, LDH-B, MDH-1, ME-1, PGM, and SOD), all alleles were specific to each genus.

The mean proportion of heterozygous loci per individual, mean proportion of polymorphic loci per population, and mean number of alleles per locus in 11 species were $0-11.0 \%(\bar{x}=4.5 \%)$, $0-40.0 \%(\bar{x}=12.5 \%)$, and 1.00-1.40 ( $\bar{x}=1.14)$, respectively (Table 5 ). There were no obvious differences between the actual and expected values of the first measure of genetic variability.

Genetic distances among the 11 species examined are shown in Table 6 . The distances were 0.036 between two populations of Litoria in- 

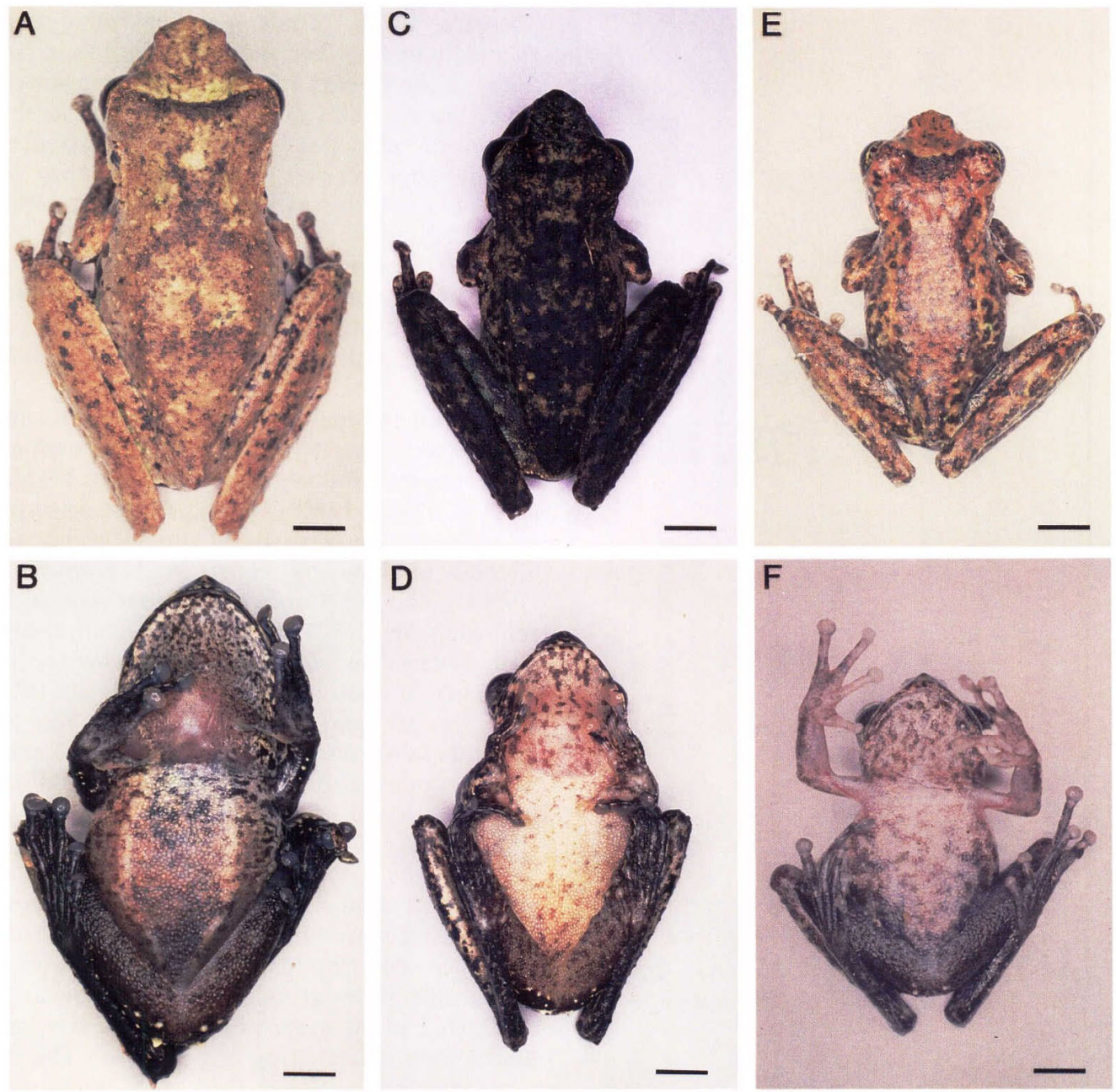

FIG. 1. Papua New Guinean hylid frogs. Scale bars equal $5 \mathrm{~mm}$. A, B: Litoria arfakiana. C, D: Litoria wollastoni. E, F: Litoria pratti group sp. The head of L. pratti group sp. is broad and its snout is angular and projected (E, F), but usually not so acutely as in members of the L. arfakiana group (A-D). There are spikes on the heels of frogs of the L. arfakiana group (A-D), whereas there are no spikes on the heels of the frogs of $L$. pratti group sp. (E, F).

frafrenata, and $0.248-1.849(\bar{x}=1.135)$ between nine species of the genus Litoria. Of the latter, the distance value was smallest between $L$. wollastoni and $L$. arfakiana (0.248), the second smallest between $L$. contrastens and $L$. bicolor group sp. (0.357), and the greatest between $L$. arfakiana and $L$. sp. from Lae (1.849). Genetic distance was 1.703 between two Nyctimystes species examined. Between Litoria and $\mathrm{Ny}$ ctimystes, genetic distances were 1.551-2.877 $(\overline{\mathrm{x}}=1.944)$.

The primary divergence expressed in the UPGMA dendrogram (Fig. 3A) was concordant with the generic classification of the present samples. The genus Litoria was divided into two subgroups; one containing $L$. arfakiana, $L$. wollastoni, $L$. angiana, and $L$. pratti group sp., and the other containing $L$. contrastens, $L$. bicolor group sp., L. thesaurensis, $L$. infrafrenata, and $L$. sp. from Lae. Two species of $N y$ ctimystes were remotely related to each other. The NJ tree (Fig. 3B) also showed that the New Guinean hylids primarily diverged into two genera, Nyctimystes and Litoria, but then the latter gradually diverged into several species groups. In contrast to the UPGMA dendro- 

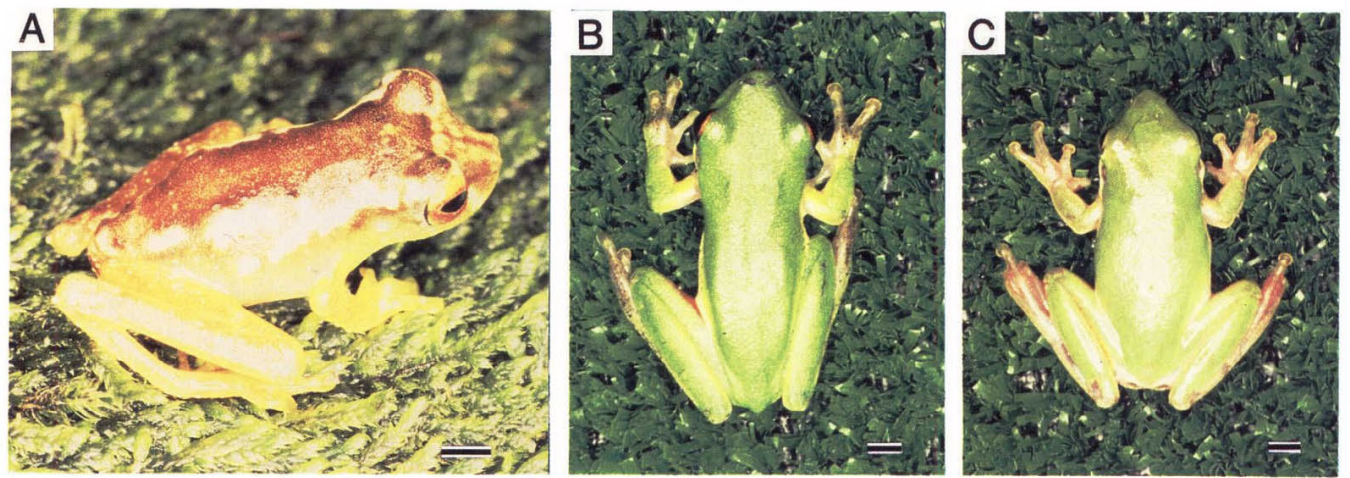

Fig. 2. Papua New Guinean hylid frogs. Scale bars equal $2.5 \mathrm{~mm}$. A: Litoria sp. collected at Lae. B: Litoria contrastens. C: Litoria bicolor group sp. Litoria contrastens is very similar to L. bicolor group sp. in external morphology and coloration.

gram, the NJ tree showed that Litoria infrafrenata was first differentiated from the other Litoria species.

\section{Discussion}

According to Zweifel and Tyler (1982) and Frost (1985), all hylid frogs of the New Guinean region (71 species) belong to only two genera: Nyctimystes and Litoria. The former lives predominantly in montane habitats and centers upon the mainland, whereas the latter ranges throughout New Guinea and is the most diverse group of frogs in the region. Tyler and Davies (1979) examined the phylogenetic relationships and evolution of Nyctimystes, and suggested that this genus originated from a montane Litoria stock resembling L. eucnemis. Examining 22
Litoria and 6 Nyctimystes species from Papua New Guinea, Menzies and Tippett (1976) reported that the chromosome number of Papuan hylids is $2 n=26$, with the exception of $L$. infrafrenata, which has $2 n=24$ chromosomes. Kuramoto and Allison (1991) also reported the karyotypes of three species of Litoria ( $L$. arfakiana, L. thesaurensis, L. wollastoni) and two species of Nyctimystes ( $N$. foricula, N. pulchra) from Papua New Guinea, and suggested that the karyotype of Nyctimystes was derived from that of a group of Litoria. Our results showed that the New Guinean hylids examined in this study are largely divided into two groups, Litoria and Nyctimystes. The genetic distances between the two genera, 1.551-2.877 $(\overline{\mathrm{x}}=1.944)$, were large compared with those within each of

TABLE 2. Enzymes analyzed in the present study.

\begin{tabular}{lllll}
\hline \multicolumn{1}{c}{ Enzyme } & Abbreviation & E.C.No. ${ }^{\text {a) }}$ & \multicolumn{1}{c}{ Tissue } & Buffer system $^{\text {b) }}$ \\
\hline Aspartate aminotransferase & AAT & 2.6 .1 .1 & Skeletal muscle & T-C pH 7.0 \\
Adenylate kinase & AK & 2.7 .4 .3 & Skeletal muscle & T-C pH 7.0 \\
Creatine kinase & CK & 2.7 .3 .2 & Skeletal muscle & T-B-E pH 8.0 \\
$\alpha$-Glycerophosphate dehydrogenase & $\alpha$-GDH & 1.1 .1 .8 & Skeletal muscle & T-C pH 6.0 \\
Glucose phosphate isomerase & GPI & 5.3 .1 .9 & Skeletal muscle & T-B-E pH 8.0 \\
Isocitrate dehydrogenase & IDH & 1.1 .1 .42 & Skeletal muscle & T-C pH 7.0 \\
Lactate dehydrogenase & LDH & 1.1 .1 .27 & Skeletal muscle & T-C pH 6.0 \\
Malate dehydrogenase & MDH & 1.1 .1 .37 & Skeletal muscle & T-C pH 6.0 \\
Malic enzyme & ME & 1.1 .1 .40 & Skeletal muscle & T-C pH 7.0 \\
Mannose phosphate isomerase & MPI & 5.3 .1 .8 & Skeletal muscle & T-C pH 7.0 \\
Peptidase & PEP & 3.4 .3 .1 & Liver & T-B-E pH 8.0 \\
Phosphogluconate dehydrogenase & PGD & 1.1 .1 .44 & Skeletal muscle & T-C pH 7.0 \\
Phosphoglucomutase & PGM & 2.7 .5 .1 & Skeletal muscle & T-B-E pH 8.0 \\
Superoxide dismutase & SOD & 1.15 .1 .1 & Skeletal muscle & T-B-E pH 8.0 \\
\hline
\end{tabular}

a) Enzyme Commission numbers (Nomenclature Committee of Biochemistry, 1992).

b) $\mathrm{T}-\mathrm{C}=$ Tris-citrate buffer; $\mathrm{T}-\mathrm{B}-\mathrm{E}=$ Tris-borate-EDTA buffer. 
Table 3. The Numbers and kinds of alleles and phenotypes at 20 enzyme loci in 11 species belonging to two genera of the family Hylidae in Papua New Guinea.

\begin{tabular}{|c|c|c|c|c|}
\hline \multirow[b]{2}{*}{ Loci } & \multicolumn{2}{|c|}{ Alleles } & \multicolumn{2}{|r|}{ Phenotypes } \\
\hline & $\mathbf{N}$ & Kind & $\mathbf{N}$ & Kind \\
\hline AAT-1 & 7 & $\mathrm{a}-\mathrm{g}$ & 9 & $\mathrm{BB}, \mathrm{CC}, \mathrm{DD}, \mathrm{EE}, \mathrm{FF}, \mathrm{GG}, \mathrm{AC}, \mathrm{BC}, \mathrm{DF}$ \\
\hline AAT-2 & 5 & a-e & 6 & $\mathrm{AA}, \mathrm{BB}, \mathrm{CC}, \mathrm{DD}, \mathrm{EE}, \mathrm{AD}$ \\
\hline AK & 4 & a-d & 6 & $\mathrm{AA}, \mathrm{BB}, \mathrm{CC}, \mathrm{DD}, \mathrm{BC}, \mathrm{CD}$ \\
\hline CK & 3 & $a-c$ & 3 & $\mathrm{AA}, \mathrm{BB}, \mathrm{CC}$ \\
\hline$\alpha-\mathrm{GDH}$ & 3 & $a-c$ & 4 & $\mathrm{AA}, \mathrm{BB}, \mathrm{CC}, \mathrm{AB}$ \\
\hline GPI & 5 & a-e & 8 & $\mathrm{AA}, \mathrm{BB}, \mathrm{CC}, \mathrm{DD}, \mathrm{EE}, \mathrm{AC}, \mathrm{BD}, \mathrm{BE}$ \\
\hline IDH-1 & 9 & $a-i$ & 10 & $\mathrm{AA}, \mathrm{BB}, \mathrm{CC}, \mathrm{DD}, \mathrm{EE}, \mathrm{FF}, \mathrm{GG}, \mathrm{HH}, \mathrm{II}, \mathrm{EH}$ \\
\hline IDH-2 & 4 & a-d & 5 & $\mathrm{AA}, \mathrm{BB}, \mathrm{CC}, \mathrm{DD}, \mathrm{BD}$ \\
\hline LDH-A & 4 & a-d & 4 & $\mathrm{AA}, \mathrm{BB}, \mathrm{CC}, \mathrm{DD}$ \\
\hline LDH-B & 7 & a-g & 8 & $\mathrm{AA}, \mathrm{BB}, \mathrm{CC}, \mathrm{DD}, \mathrm{EE}, \mathrm{FF}, \mathrm{GG}, \mathrm{CE}$ \\
\hline MDH-1 & 5 & a-e & 5 & $\mathrm{AA}, \mathrm{BB}, \mathrm{CC}, \mathrm{DD}, \mathrm{EE}$ \\
\hline MDH-2 & 5 & a-e & 6 & $\mathrm{AA}, \mathrm{BB}, \mathrm{CC}, \mathrm{DD}, \mathrm{EE}, \mathrm{AE}$ \\
\hline ME-1 & 5 & a-e & 5 & $\mathrm{AA}, \mathrm{BB}, \mathrm{CC}, \mathrm{DD}, \mathrm{EE}$ \\
\hline ME-2 & 4 & a-d & 5 & $\mathrm{AA}, \mathrm{BB}, \mathrm{CC}, \mathrm{DD}, \mathrm{AC}$ \\
\hline MPI & 7 & a-g & 11 & $\mathrm{BB}, \mathrm{CC}, \mathrm{DD}, \mathrm{EE}, \mathrm{FF}, \mathrm{GG}, \mathrm{AG}, \mathrm{BE}, \mathrm{BG}, \mathrm{CG}, \mathrm{DG}$ \\
\hline PEP-A & 5 & a-e & 5 & $\mathrm{AA}, \mathrm{BB}, \mathrm{CC}, \mathrm{DD}, \mathrm{EE}$ \\
\hline PEP-D & 5 & a-e & 6 & $\mathrm{AA}, \mathrm{BB}, \mathrm{CC}, \mathrm{DD}, \mathrm{EE}, \mathrm{AC}$ \\
\hline PGD & 6 & $a-f$ & 9 & $\mathrm{AA}, \mathrm{BB}, \mathrm{CC}, \mathrm{DD}, \mathrm{EE}, \mathrm{FF}, \mathrm{BD}, \mathrm{CD}, \mathrm{DE}$ \\
\hline PGM & 4 & a-d & 4 & $\mathrm{AA}, \mathrm{BB}, \mathrm{BC}, \mathrm{BD}$ \\
\hline SOD & 9 & $a-i$ & 10 & $\mathrm{AA}, \mathrm{BB}, \mathrm{CC}, \mathrm{EE}, \mathrm{FF}, \mathrm{GG}, \mathrm{HH}, \mathrm{II}, \mathrm{CH}, \mathrm{DG}$ \\
\hline Average & 5.3 & & 6.5 & \\
\hline
\end{tabular}

them $(0.248-1.849, \bar{x}=1.135)$. Both the UPGMA dendrogram and the $\mathrm{NJ}$ tree showed a primary dichotomy of the New Guinean hylids $N y$ ctimystes and Litoria. This result contradicts the hypothesis of Tyler and Davies (1979), who assumed that the numerous points of morphological and reproductive resemblance of $\mathrm{Ny}$ ctimystes to montane species of Litoria reflect a common origin of Nyctimystes and the montane Litoria. Of 11 species examined in the present study, only $L$. infrafrenata and $L$. bicolor group sp. inhabit the lowlands of New Guinea, and the other nine species are found in hilly forests or the mountains (Menzies, 1976; Tyler and Davies, 1979). The present data showed no close relationships between Nyctimystes and montane Litoria. Thus, it is probable that after the common ancestor(s) diverged into the two genera, Litoria and Nyctimystes, they have independently acquired montane adaptations.

Dessauer et al. (1977) indicated a wide divergence in 16 proteins among 13 species of Litoria that was in concordance with morphological divergence. Based on this, they suggested the presence of two distinct lineages in the species they examined. Their biochemical data, while supporting the recognition of two pairs of sibling species (L. arfakiana and $L$. wollastoni, and L. modica-like frogs from two localities), suggested that a third cryptic species may exist in the former pair. According to Menzies and Zweifel (1974), Litoria arfakiana and L. wollastoni cannot be clearly distinguished from each other morphologically (although there is an average size difference: see Menzies and Zweifel, 1974), but do differ in mating calls. The present study showed that, although the genetic distance between these two species is relatively small $(0.248)$, they are clearly distinguished by diagnostic alleles at four loci (IDH-1, PEP-A, PEP$\mathrm{D}$ and SOD). This confirms the taxonomic conclusion by Dessauer et al. (1977), which was made on the basis of very few specimens for each species. It is interesting to note that no genetic variability was observed in $L$. wollastoni, whereas comparatively high genetic variability was found in L. arfakiana. These results may reflect the differences between ecological and habitat characteristics of these two species (Dessauer et al., 1975). On the other hand, Litoria contrastens is very similar to members of the $L$. bicolor group in external morphology and coloration (Fig. 2B, C). The genetic distance between $L$. contrastens and $L$. bicolor group $\mathrm{sp}$. was comparatively small $(0.357)$, but they were distinguished by diagnostic alleles at six loci 


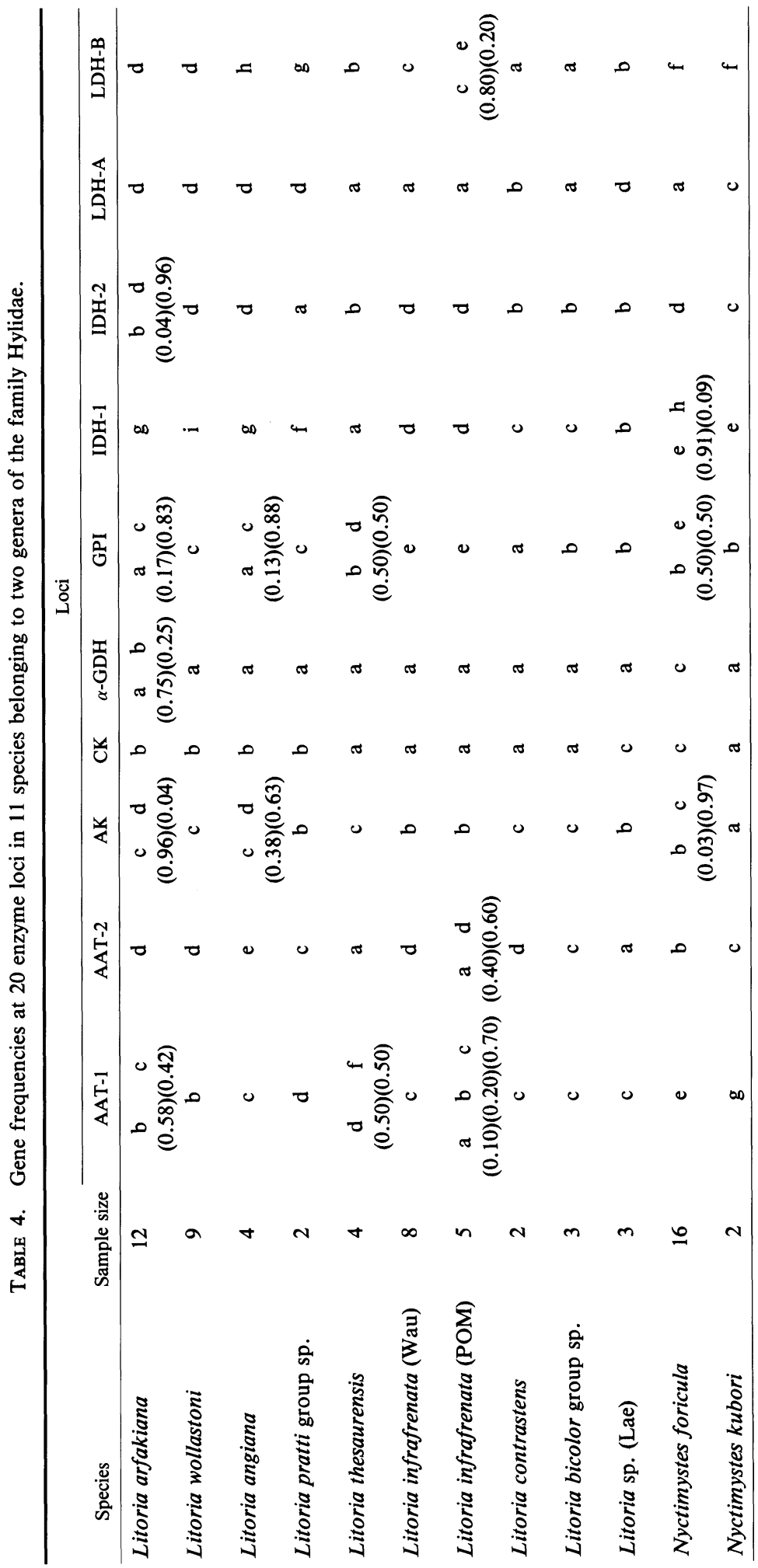




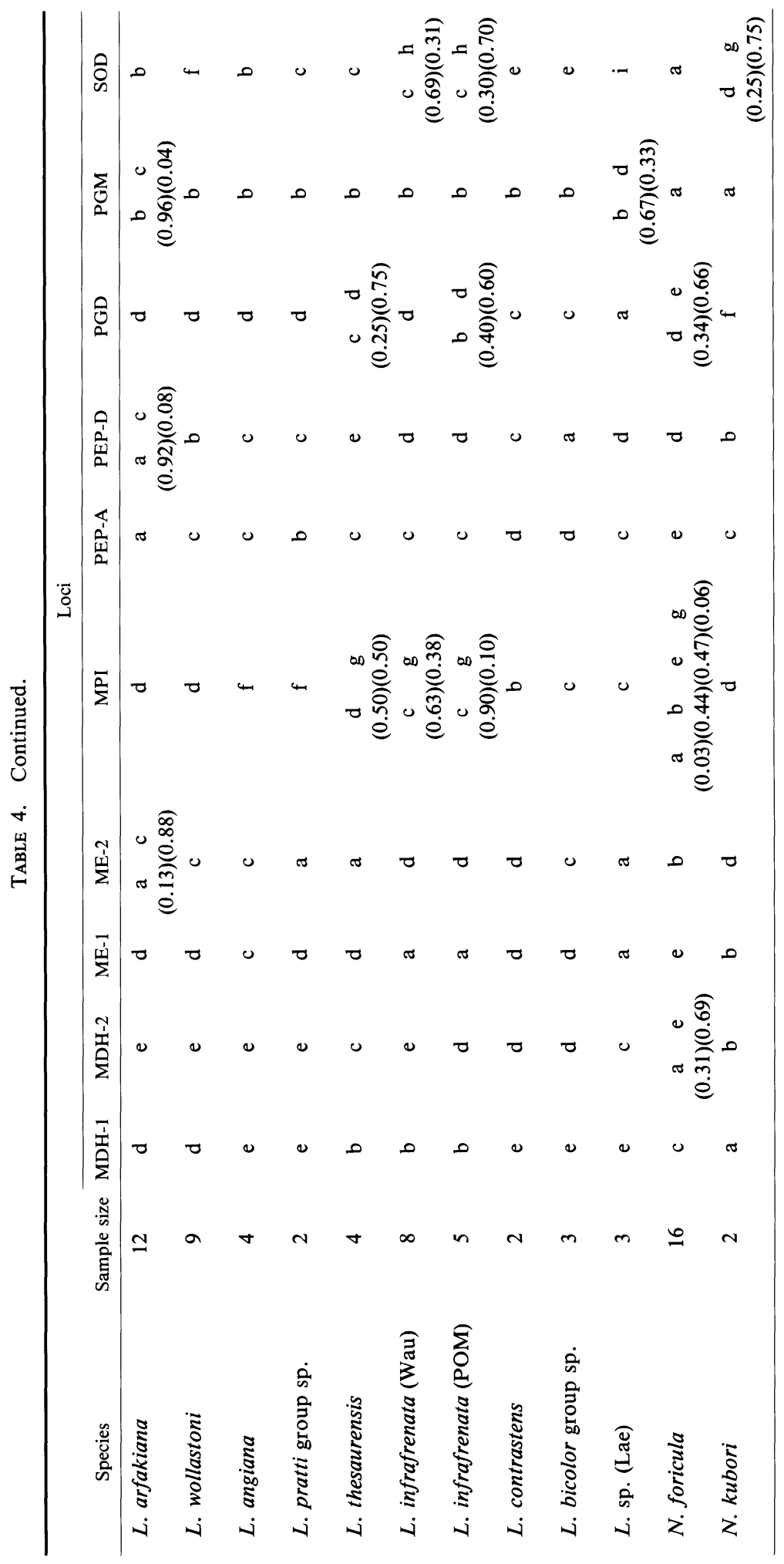


TABle 5. Genetic variabilities at 20 enzyme loci in 11 species belonging to two genera of the family Hylidae.

\begin{tabular}{lcccc}
\hline \multicolumn{1}{c}{ Species } & $\begin{array}{c}\text { Sample } \\
\text { size }\end{array}$ & $\begin{array}{c}\text { Mean proportion (\%) } \\
\text { of heterozygous loci } \\
\text { per individuala) }\end{array}$ & $\begin{array}{c}\text { Mean proportion (\%) } \\
\text { of polymorphic loci } \\
\text { per population }\end{array}$ & $\begin{array}{c}\text { Mean number } \\
\text { of alleles } \\
\text { per locus }\end{array}$ \\
\hline Litoria arfakiana & 12 & $7.5(8.8)$ & 40.0 & 1.40 \\
Litoria wollastoni & 9 & $0(0)$ & 0 & 1.00 \\
Litoria angiana & 4 & $5.0(3.4)$ & 10.0 & 1.10 \\
Litoria pratti group sp. & 2 & $0(0)$ & 0 & 1.00 \\
Litoria thesaurensis & 4 & $10.0(9.4)$ & 20.0 & 1.20 \\
Litoria infrafrenata (Wau) & 8 & $5.6(4.5)$ & 10.0 & 1.10 \\
Litoria infrafrenata (POM) & 5 & $11.0(11.7)$ & 30.0 & 1.35 \\
Litoria contrastens & 2 & $0(0)$ & 0 & 1.00 \\
Litoria bicolor group sp. & 3 & $0(0)$ & 5.0 & 1.05 \\
Litoria sp. (Lae) & 3 & $3.3(2.2)$ & 30.0 & 1.40 \\
Nyctimystes foricula & 16 & $8.8(11.0)$ & 5.0 & 1.05 \\
Nyctimystes kubori & 2 & $2.5(1.9)$ & 12.5 & 1.14 \\
\hline \multicolumn{1}{c}{ Average } & 5.8 & $4.5(4.4)$ & & \\
\hline
\end{tabular}

a) Parentheses show an expected value.

TABLE 6. Nei's (1972) genetic distance (D) among 11 species belonging to the genera Litoria (L.) and $N y$ ctimystes $(N$.$) .$

\begin{tabular}{|c|c|c|c|c|c|c|c|c|c|c|c|}
\hline \multirow[b]{2}{*}{ Species } & \multicolumn{11}{|c|}{ Species } \\
\hline & 1 & 2 & 3 & 4 & 5 & 6 & 7 & 8 & 9 & 10 & 11 \\
\hline 1 L. arfakiana & & & & & & & & & & & \\
\hline 2 L. wollastoni & 0.248 & & & & & & & & & & \\
\hline 3 L. angiana & 0.519 & 0.651 & & & & & & & & & \\
\hline 4 L. pratti group sp. & 0.781 & 0.916 & 0.592 & & & & & & & & \\
\hline 5 L. thesaurensis & 1.275 & 1.114 & 1.512 & 1.288 & & & & & & & \\
\hline 6 L. infrafrenata (Wau) & 1.301 & 1.181 & 1.164 & 1.586 & 0.892 & & & & & & \\
\hline 7 L. infrafrenata (POM) & 1.435 & 1.247 & 1.248 & 1.653 & 0.910 & 0.036 & & & & & \\
\hline 8 L. contrastens & 1.268 & 1.386 & 1.273 & 1.386 & 1.114 & 1.027 & 1.093 & & & & \\
\hline 9 L. bicolor group sp. & 1.172 & 1.386 & 1.296 & 1.386 & 0.899 & 1.082 & 1.046 & 0.357 & & & \\
\hline 10 L.sp. (Lae) & 1.849 & 1.685 & 1.232 & 1.250 & 0.835 & 0.975 & 0.885 & 1.444 & 1.087 & & \\
\hline $11 N$. foricula & 1.821 & 1.839 & 2.047 & 2.877 & 1.969 & 1.554 & 1.555 & 2.596 & 2.034 & 1.998 & \\
\hline 12 N. kubori & 2.381 & 1.600 & 2.276 & 2.293 & 1.551 & 1.577 & 1.538 & 1.888 & 1.600 & 1.876 & 1.703 \\
\hline
\end{tabular}

(AAT-2, GPI, LDH-A, ME-2, MPI, and PEPD). This confirms their distinctiveness at the species level.

Litoria infrafrenata in New Guinea appears to be split into several geographic populations (Tyler, 1994). Dessauer et al. (1977), for example, showed distinct biochemical differentiation between two populations, the Daru and Garaina populations, of $L$. infrafrenata. According to them, this widely ranging species probably includes some populations which are at least in the early stage of speciation. However, no genetic differentiation was evident between the Wau and Port Moresby populations of this species in the present study (0.036 in genetic distance), despite their distinct geographical isolation by high mountain ranges such as the Owen Stanley.
According to Menzies (1976), all torrent breeding species of the New Guinean Litoria other than $L$. angiana and members of the $L$. arfakiana group (L. arfakiana, L. wollastoni and $L$. oenicolen), could be included in the $L$. pratti group. In the $L$. pratti group, the snoutvent length of males does not grow longer than $38 \mathrm{~mm}$ (often much less), and the dorsal color is mostly brown (Menzies, 1976). Their heads are broad, and their snouts are angular and projecting, but usually not so acutely as in members of the L. arfakiana group. The fingers are unwebbed and there are no spikes on the heels in the $L$. pratti group (Fig. 1). This last trait serves to distinguish them from frogs of the $L$. arfakiana group, whereas the small size distinguishes them from L. angiana. However, the 

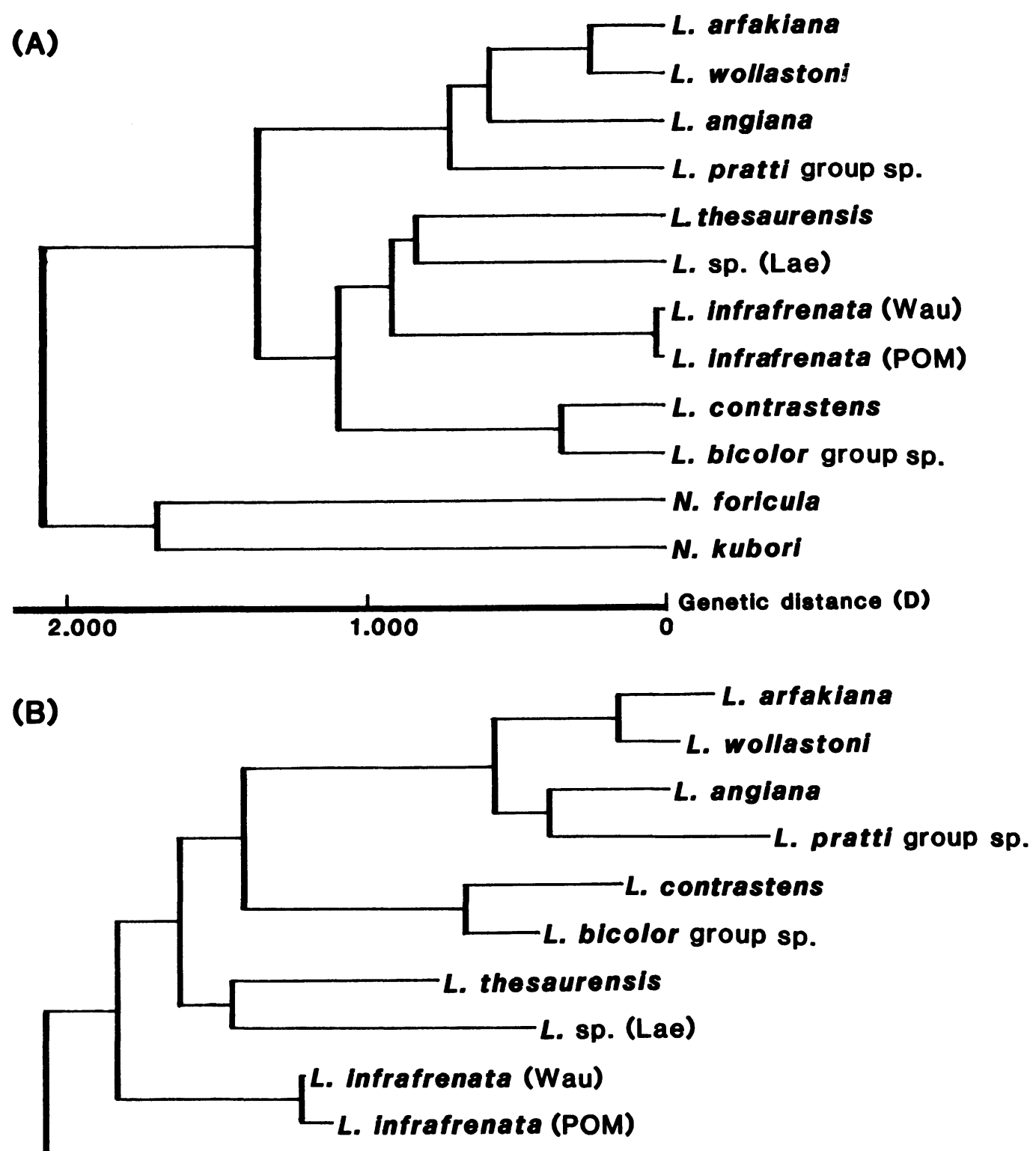

N. foricula

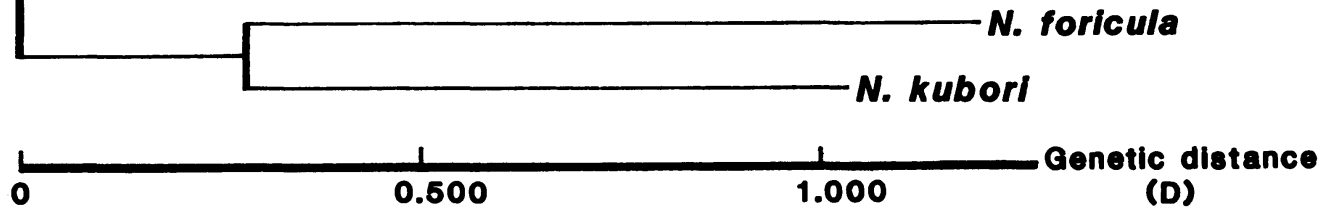

FIG. 3. UPGMA dendrogram (A) and NJ tree (B) for 11 species of Papua New Guinean hylid frogs belonging to two genera of the family Hylidae based on Nei's (1972) genetic distance.

present study revealed that four torrent breeding species, L. arfakiana, L. wollastoni, L. angiana, and $L$. pratti group sp., are relatively closely related to each other, constituting a single cluster
(0.248-0.916, $\overline{\mathrm{x}}=0.618$ in genetic distances) (Fig. $3)$.

A possible undescribed species from Lae (Fig. 2A) formed a cluster with $L$. thesaurensis, 
although this species was distinctly differentiated from the latter and other congeneric species (0.835-1.998, $\overline{\mathrm{x}}=1.374$ in genetic distances). Available specimens representing this problematic species are all basically dark brown and blotched with a considerable amount of yellow, and there is a light line connecting the upper eyelids (Fig. 2A). Their heads are broad, and the snouts are angular. Tyler et al. (1986) pointed out the existence of a large number of undescribed species in the Papua New Guinean hylids. This species is likely to be recognized as a valid new species of genus Litoria, although further examination is needed to describe this species.

ACKNowledgments.-We are especially indebted to T. Nakajima of Tokyo University, who was the Representative of Field Research Project in Papua New Guinea, for his invaluable support in numerous ways throughout the field work. We are also grateful to M. Kuramoto of Fukuoka University of Education for his kindness in providing us with valuable specimens. We also thank Y. Komiya of Tokyo University, the other participants of this project and the staff of Wau Ecology Institute for their cooperation and aid in collecting specimens in Papua New Guinea. Field work in Papua New Guinea was supported by a Grant-in-Aid for Overseas Scientific Survey from the Ministry of Education, Science and Culture, Japan (No. 59041025).

\section{Literature Cited}

Dessauer, H. C., D. F. Gartside, and R. G. ZWEIFEL. 1977. Protein electrophoresis and the systematics of some New Guinea hylid frogs (genus Litoria). Syst. Zool. 26: 426-436.

Dessauer, H. C., E. Nevo, and K.-C. Chuang. 1975. HIGH GENETIC VARIABILITY IN AN ECOLOGICALLY VARIABLE VERTEBRATE, Bufo viridis. Biochem. Genet. 13(9/10): 651-661.

Frost, D. R. (ed.). 1985. Amphibian Species of the World: A Taxonomic and Geographical Reference. Allen Press, Lawrence, Kansas. i-v+732 p.

HaRris, H. AND D. A. Hopkinson. 1976. Handbook of Enzyme Electrophoresis in Human Genetics. North-Holland, Amsterdam.

Kuramoto, M. And A. Allison. 1991. Karyotypes of five hylid frogs from Papua New Guinea, with a discussion on their systematic implications. Jpn. J. Herpetol. 14(1): 6-11.

Menzies, J. I. 1976. Handbook of Common New Guinea Frogs. Wau Ecology Institute, Papua New Guinea. $75 \mathrm{p}$.
Menzies, J. I. AND J. Tippett. 1976. Chromosome number of Papuan hylid frogs and the karyotype of Litoria infrafrenata (Amphibia, Anura, Hylidae). J. Herpetol. 10(3): 167-173.

MenZIES, J. I. AND R. G. ZWEIFEL. 1974. Systematics of Litoria arfakiana of New Guinea and sibling species (Salientia, Hylidae). Am. Mus. Novit. (2258): 1-16.

NEI, M. 1972. Genetic distance between populations. Amer. Natur. 106(949): 283-292.

NeI, M. 1975. Molecular Population Genetics and Evolution. North-Holland, Amsterdam. 288 p.

NEI, M. 1987. Molecular Evolutionary Genetics. Columbia Univ. Press, New York. 512 p.

Nishoka, M., H. Ohtani, ANd M. Sumida. 1980. Detection of chromosomes bearing the loci for seven kinds of proteins in Japanese pond frogs. Sci. Rep. Lab. Amphibian Biol. Hiroshima Univ. 4: 127-184.

NishoKa, M., M. Sumida, and H. Ohtani. 1992. Differentiation of 70 populations in the Rana nigromaculata group by the method of electrophoretic analyses. Sci. Rep. Lab. Amphibian Biol. Hiroshima Univ. 11: 1-70.

Nomenclature COMMITTEE OF THE INTERNATIONAL UNION OF BIOCHEMISTRY. 1992. Enzyme Nomenclature 1992. Academic Press, New York.

SaItou, N. ANd M. NeI. 1987. The neighbor-joining method: A new method for reconstructing phylogenetic trees. Mol. Biol. Evol. 4(4): 406-425.

Sneath, P. H. A. AND R. R. Sokal. 1973. Numerical Taxonomy. W. H. Freeman and Company, San Francisco. 573 p.

Tyler, M. J. 1994. Australian Frogs: A Natural History. Griffin Press, Australia. 192 p.

Tyler, M. J. AND M. DAVIES. 1979. Redefinition and evolutionary origin of the Australopapuan hylid frog genus Nyctimystes Stejneger. Aust. J. Zool. 27: 755-772.

Tyler, M. J., M. Davies, ANd K. Aplin. 1986. A new stream-dwelling species of Litoria (Anura: Hylidae) from New Guinea. Trans. Roy. Soc. S. Aust. 110(2): 63-67.

ZweIfel, R. G. 1983. Two new hylid frogs from Papua New Guinea and a discussion of the Nyctimystes papua species group. Am. Mus. Novit. (2759): 1-21. ZWeIfEl, R. G. AND M. J. Tyler. 1982. Amphibia of New Guinea. In: J. L. Gressitt (ed.), Biogeography and Ecology of New Guinea. p. 759-801. W. Junk, The Hague.

Laboratory for Amphibian Biology, Faculty of Science, Hiroshima University, Higashihiroshima 739-8526 JAPAN (MS and MN), and Division of Vertebrate Zoology, Bishop Museum, Honolulu, Hawaii, 96817 USA (AA) 
要旨 アロザイム分析によるパプアニューギニ ア産アマガエル科のカエル類の遗伝的関係 と系統

住田正幸・アレン =アリソン・西岡みどり パプアニューギニア産アマガエル科の Litor ia 属 9 種と Nyctimystes 属 2 種の計70個体を用 いて，肝臓扣よび骨格筋の14酵素をデンプンゲ ル電気泳動法によって分析した。 これらの酵素 には20の遺伝子座が関与し, 各遺伝子座にはそ れぞれ3-9 の対立遺伝子によって生じる 3-11 の表現型が観察された. 各種における平均へテ 口接合体率は $4.5 \%$, 多型的遺伝子座の割合は $12.5 \%$, 遺伝子座当たりの平均対立遺伝子数は 1.14であった. Nei の遺伝距離は L. infrafrenata の 2 集団間では0.036, Litoria 属内の 9 種間 では0.248-1.849 (平均1.135), Nyctimystes 属 内の 2 種間では1.703, Litoria と Nyctimystes の 2 属間では1.551-2.877（平均1.944）であっ
た. UPGMA 法および NJ 法による系統分析の 結果, ニューギニア産アマガェル科はLitoria 属とNyctimystes 属の 2 つに大きく分岐するこ とが分かった。また本結果により，Litoria 属 内の形態的によく似たいくつかの種（L. arfakiana と L. wollastoni, L. contrastens と L. bicolor 種群未記載種）が明瞭に識別できるこ とが確認された。

（739-8526 東広島市鏡山 1-3-1 広島大学理 学部附属両生類研究施設 (住田 - 西岡) ・ ア リカ合衆国ハワイ州ホノルル市ビショップ博 物館（アレン＝アリソン)） 